\title{
Üniversite öğrencilerinin geleneksel gıda farkındalığı üzerine bir araştırma
}

\author{
A research on awareness of university students for traditional foods
}

\author{
Gülşen KESKIN ${ }^{1 \mathscr{C}(D)}$, Nuran TAPKI ${ }^{1}$ (D) Erdal DAĞISTAN $^{1}$ (D) \\ ${ }^{1}$ Hatay Mustafa Kemal Üniversitesi, Ziraat Fakültesi, Tarım Ekonomisi Bölümü, Antakya-Hatay, Türkiye.
}

MAKALE BILGISI / ARTICLE INFO

Makale tarihçesi / Article history:

DOI: $\underline{10.37908 / m k u t b d .952129}$

Geliş tarihi /Received:14.06.2021

Kabul tarihi/Accepted:16.07.2021

\section{Keywords:}

Traditional foods, geographical indication, consumer perception.

\footnotetext{
Corresponding author: Gülşen KESKIN

$\triangle$ : gulsen.keskin@mku.edu.tr
}

\section{ÖZET / A BSTR A C T}

\section{Atıf / Citation: Keskin G, Tapkı N, Dağıstan E (2021) Üniversite öğrencilerinin geleneksel gıda farkındalığı üzerine bir araştırma MKU. Tar. Bil. Derg. 26(3) : 565-575. DOI: 10.37908/mkutbd.952129}

\section{GiRiş}

Dünya'da ürünlerin kalitesi ve kaynağına olan ilginin artması, geleneksel gıdaları ve coğrafi işaretleri önemli bir ekonomik güce dönüştürmüştür. Geleneksel gıdalar, coğrafi işaretlerin de kaynağını oluşturduğu için geleneksel gıdalar bakımından zengin olan ülkelerin coğrafi işaret potansiyeli de artmaktadır. Coğrafi işaretlerin geleneksel bilgi ve kültürel değerleri koruma, ürün taklitçiliği ile mücadele etme, yerel üretimi ve kırsal kalkınmayı destekleme, pazarlama aracı olma ve üretim metodunu ve ürünün standardını garanti etme gibi birçok işlevi vardır.

Türkiye'de 2017 yılına kadar coğrafi işaret korumasının yasal dayanağını 555 sayılı Kanun Hükmünde Kararname (KHK) ile bu kararnamenin Uygulama Yönetmeliği ve 
5805 sayılı Coğrafi İşaretlerin Korunması Hakkındaki Kanun Hükmünde Kararnamede Değişiklik Yapılmasına Dair Kanun oluşturmuştur. Coğrafi işaretler ve geleneksel ürün adları, 2017 yılında yürürlüğe giren 6769 sayılı Sinai Mülkiyet Kanunu ile yeni bir boyut kazanmıştır. Sinai Mülkiyet kanununun 34. maddesi mahreç ve menşe işaretinin tanımını yapmakta ve bu kapsama girmeyen ve ilgili piyasada bir ürünü tarif etmek için geleneksel olarak en az 30 yıl süreyle kullanıldığı kanıtlanan adlar, geleneksel üretim veya işleme yöntemi yahut geleneksel bileşimden kaynaklanma ve/veya geleneksel hammadde veya malzemeden üretilmiş olma şartlarından en az birini sağlaması durumunda geleneksel ürün adı olarak tanımlanmaktadır. Böylece, Türk mevzuatında 6769 sayılı kanun ile $A B^{\prime}$ de (Anonymous, 2012) olduğu gibi geleneksel özellikli ürünlere ilişkin bir düzenlemeye yer verilmiştir. Ulusal politikaların belirlenmesi açısından önemli olan Ulusal Coğrafi İşaret Strateji Belgesi ve Eylem Planında ise 5 stratejik hedef yer almaktadır. Bunlar;

1. Ülke ihtiyaçları doğrultusunda, ulusal ve uluslararası gelişmelere paralel şekilde mevzuat ve uygulamaların geliştirilmesi (Sinai Mülkiyet kanunu ile kısmen yapılmıştır),

2. İlgili kurumlarda coğrafi işareti destekleyecek yönde kurumsal kapasitede iyileştirme yapılması, coğrafi işaretlere ilişkin bilimsel çalışmaların teşvik edilmesi, kurumlar arası koordinasyonun güçlendirilmesi,

3. Toplumun her kesiminde coğrafi işaretlere ilişkin bilinç ve farkındalığın artırılması, eğitim-öğretim programları kapsamına alınması,

4. Coğrafi işaretlerin başvuru, inceleme ve denetleme aşamalarına ilişkin altyapının güçlendirilmesi, belirlenen coğrafi alanda tescile konu coğrafi işaretli ürün üreticilerinin tespit edilmesi, üretici kaydının coğrafi işaret denetimi için esas teşkil etmesi ve elektronik platform oluşturulması,

5. Coğrafi işaretli ürünlerin katma değerinin yükseltilmesi amacıyla pazarlama stratejilerinin etkinliğinin artırımasıdır.

Ulusal düzeyde önemli belgelerden biri olan tarım stratejisi belgesinde de coğrafi işaretli ürünlerin bilinirliği, tanınırlığı ve farkındalığında eksiklikler olduğu ve yöresel ve coğrafi işaretli ürünlerin tanıtımına yönelik faaliyetlerin artırılması gerektiği belirtilmiştir. Kırsalda gelir ve istihdam olanaklarının artırılması ve kırsal ekonomiyi çeşitlendirme hedefinde ise geleneksel gıda, geleneksel ürünler ve el sanatları üretiminin artırılması uygulanacak strateji olarak belirlenmiştir (TOB, 2021).

Türkiye, geleneksel/yerel/yöresel tarım ürünleri ve gıdalarda zengin bir çeşitliliğe ve üretim potansiyeline sahiptir. Bu ürünler, ait olduğu ülkenin/bölgenin tanıtımına ve ekonomisine katkı sağlamakta ve özellikle küresel pazarlarda farklılaşma yaratmada önemli bir araç olarak kullanılmaktadır (Keskin, 2017). Küreselleşmenin giderek yaygınlaştığı günümüzde pazarda tutunabilmenin en önemli yolu farklılaşmak olmuştur. Bu nedenle de 21. yüzyılda dünya küreselleşse de, bu olguya karşılık yükselen trend, "gelenekselleşmek" olmuştur (Demirbaş ve ark., 2006). Türkiye'de geleneksel gıdalar denildiğinde, değişik bölgelerde üretilen yöresel gıdalar anlaşılmakta ve bu gıdaların üretildiği bölgeye özgü tat, aroma ve bileşim gibi özelliklere sahip oldukları bilinmektedir (Tan, 2004; Aktaran Özdemir ve ark., 2017). Geleneksel gıdalar; sık sık tüketilen ya da bir kutlama ve/veya dönemle ilgili, bir nesilden diğerine aktarılan, gastronomik mirasa göre özel bir işlemle yapılan, doğal olarak üretilen ve farklılaşan, duyusal özellikleri bilinen ve yerel bir alan/bölge/ülke ile ilgili olan ürünler şeklinde tanımlanmaktadır (Taşdan ve ark., 2014; Onurlubaş ve Taşdan 2016). Özdemir ve ark. (2015) ise geleneksel gıdaları, Anadolu'nun tarihsel sürecinde farklı coğrafyaların, biyoçeşitliliğin, etnik kimliğin bir sonucu olarak yüzyıllardır kazanlarda kaynayan lezzetlerin oluşturduğu çok renklilik, kaybedilmemesi gereken bir zenginlik, önemli bir ulusal değer ve kültürel miras olarak tanımlamışlardır. Geleneksel gıdalarla ilgili benzer birçok tanımlama bulunmakla birlikte, herkes tarafından kabul edilmiş ortak bir tanım yoktur (Demirbaş ve ark., 2006; Hermann ve ark. 2008; Çoksöyler, 2011; Anonymous, 2012; Başaran, 2016; May and Tschofen, 2016; Duru ve Seçer, 2019; Başaran, 2020;). Literatürde geleneksel gıdaların ve coğrafi işaretlerin kırsal kalkınmaya ve ekonomiye etkisi (Tepe, 2008; Johannes, 2010; Altuntaş ve Gülçubuk, 2014; Kantaroğlu ve Demirbaş, 2018; Keskin ve Dağıstan 2020), tüketici tercihi ve algısı (TOB, 2009; Oraman ve ark., 2011; Hamşıoğlu, 2013; Taşdan ve ark., 2014; Başaran, 2016; Özdemir ve ark., 2017; Duru ve Seçer, 2019; Başaran, 2020) ve gençlerin gıda tüketim tercihleri (Acar, 2016; Canbolat ve Çakıroğlu, 2016; Dölekoğlu ve Çelik, 2018; Tengiz, 2018) üzerine yapılmış çok sayıda çalışma vardır. Dünya'da geleneksel gıdalara artan ilgi ve coğrafi işaret potansiyelleri, bu ürünlerin tanınırlığını ve farkındalığını artırmakta, talep ve beklentilere yön vermektedir. Tarım politikalarının oluşturulması ve uygulanmasında birinci dereceden sorumlu olan Tarım ve Orman Bakanlığı'nın da kırsal kalkınma ve coğrafi işaretler konusunda yürüttüğü çalışmalardan biri coğrafi işaretlerde farkındalığın artırılması projesidir. Bu proje kapsamında bölgesel toplantılarla teknik personelin ve bölgedeki diğer ilgili aktörlerin bilgilendirilmesi yapılmakta ve konunun önemine dikkat çekilmektedir (TOB, 2021a). Toplumun 
her kesiminde coğrafi işaretlere ilişkin bilinç ve farkındalığın artırıması, eğitim-öğretim programları kapsamına alınması ulusal strateji olarak benimsendiği için (Anonim, 2015) toplumsal farkındalığın artırılmasında geleceğin Ziraat Mühendislerinin önemli görevleri ve katkıları olacaktır. Bu nedenle, sahada görev yapacak Ziraat Mühendislerinin geleneksel ürünler ve coğrafi işaretler konusunda yüksek bir farkındalığa sahip olmaları kırsal alanın kalkınması ve toplumsal farkındalığın artırımasında önemlidir. Ziraat Fakültesi öğrencilerinin mevcut durumu gelecekteki durum hakkında önemli bilgiler sağlayacağından bu çalışmanın verileri yapılacak olan diğer çalışmalara da yol gösterecektir.

$\mathrm{Bu}$ çalışmada, toplumun diğer kesimlerinden daha duyarlı oldukları düşünülen ziraat fakültesi öğrencilerinin geleneksel gıdalar ve coğrafi işaretler konusundaki farkındalıklarının araştıııması ve mevcut durumun ortaya konulması amaçlanmıştır.

\section{MATERYAL ve YÖNTEM}

Araştırma, önemli bir potansiyele sahip olduğumuz ve günlük yaşantımızda olağan gördügümüz geleneksel gıdaların üniversite öğrencileri tarafından nasıl algılandığını ve coğrafi işaretler konusundaki bilgi düzeyleri ile bunun kaynağını belirlemeye yönelik kurgulanmıştır. Bu nedenle, çalışmanın ana materyalini, geleneksel ürünler bakımından Türkiye'nin en zengin illerinden birisi olan Hatay ilinde, ziraat temel bilim alanında lisans düzeyinde öğrenim gören öğrencilerden anket ile toplanan veriler oluşturmuştur. Bu çalışma için Hatay Mustafa Kemal Üniversitesi Sosyal ve Beşeri Bilimler Bilimsel Araştırma ve Yayın Etiği Kurulundan etik kurul kararı alınmıştır. Çalışmada kullanılan anket formları, geleneksel gıdalar ve coğrafi işaretler konusunda daha önce yapılmış çalışmalar incelenerek (Çoksöyler, 2011; Başaran, 2016; Onurlubaş ve Taşdan, 2017; Duru ve Seçer, 2019) araştırmacılar tarafından geliştirilmiştir. Ankette öğrencilere, çoktan seçmeli, likert tipi ve açık uçlu sorular olmak üzere toplam 28 soru yöneltilmiştir.

$\mathrm{Bu}$ çalışma, olasılıklı olmayan örnekleme yöntemlerinden kolayda örnekleme yöntemi ile ankete gönüllü olarak katılan 156 öğrenci ile yapıımıştır. Kolayda örnekleme, ana kütle içerisinden seçilecek örnek kesimin araştırmacının yargısı ile belirlendiği yöntemdir ve örneklemede veriler, ana kütleden en kolay, hızlı ve ekonomik şekilde toplanmaktadır (Haşığlu ve ark., 2015).

Verilerin analizinde SPSS 23 paket programı kullanılmıştır. Verilerin değerlendirilmesinde oransal dağılım ve frekans tabloları kullanılmıs ve Kruskal-Wallis ve Mann Withney $U$ testleri yapılmıştır. Likert tipi sorularda verinin niteliği nedeniyle aritmetik ortalama yerine medyan veya mod kullanılması ve parametrik olmayan testlerin yapılması daha uygun olduğundan (Turan ve ark., 2015) değerlendirmeler buna göre yapılmıştır.

\section{BULGULAR ve TARTIŞMA}

\section{Araştırmaya katılan öğrencilerin özellikleri}

Araştırmaya katılan Ziraat Fakültesi öğrencilerinin önemli bazı sosyo-demografik özellikleri Çizelge 1'de verilmiştir. Buna göre öğrencilerin \%53.85'ini erkek öğrenciler \%46.15'ini ise kız öğrenciler oluşturmaktadır. Öğrencilerin \%60.90'। 21-24 yaş grubunda, \%19.87'si 1720 yaş grubunda bulunurken, \%19.23'ü 25 yaş ve üzerindedir. Öğrencilerin $\% 39.10$ u aileleri ile birlikte yaşarken, \%60.90'ı ailelerinden ayrı yaşamaktadır. Ailelerinden ayrı yaşayan öğrencilerin $\% 40.00$ ' ı ayrı evde tek kaldıklarını, \%32.60' ı yurtta kaldıklarını, \%27.37'sı ise arkadaşları ile ortak evde kaldıklarını belirtmişlerdir. Bu durum il dışından gelen öğrencilerin daha çok olduğunu göstermektedir. Ankete katılan öğrencilerin bölümlere dağılımına bakıldığında öğrencilerin \%39.10'unun Tarım Ekonomisi, \%25.64'ünün Gıda Mühendisliği, \%25.64'ısının ise Bitki Koruma bölümlerinde öğrenim gören öğrenciler olduğu, diğer bölümlerden katılımın Bahçe Bitkileri bölümünden \%3.21, Tarla Bitkileri bölümünden $\% 2.56^{\prime}$ । ile daha düşük olduğu görülmektedir. Bu bölümler dışında ankete katılan öğrencilerin oranı ise \%3.85 olarak belirlenmiştir. Araştırmaya katılan öğrencilerin \%20.50'si 1. sınıf, \%4.50'si 2. sınif, \%26.90'। 3. sınıf, \%48.10'u 4. sinifta okumaktadır. Öğrencilerin aylık kişisel gelirleri incelendiğinde 501-1.000 TL aralı̆ı̆ında geliri olanların oranı \%43.59 olup araştırmaya katılan öğrenciler en çok bu gelir grubunda bulunmaktadır. Aylık geliri 500 TL'den düşük olan öğrencilerin oranı da \%22.44 ile yüksek bulunmuştur. Bu verilere göre öğrencilerin \%66.03'ünün oldukça düşük gelir grubunda bulunduğu anlaşılmaktadır. Öğrencilerin birçoğunun (\%60.90) ailelerinden ayrı yaşadıkları düşünüldüğünde bu durum daha da ağırlaşmaktadır. 
Çizelge 1. Ankete katılan öğrencilerin sosyo-demografik özellikleri

Table 1. Socio-demographical characteristics of the students

\begin{tabular}{|c|c|c|c|c|c|}
\hline Cinsiyet & Sayı & $\%$ & Gelir(TL/ay) & Sayı & $\%$ \\
\hline Erkek & 84 & 53.85 & $0-500$ & 34 & 22.44 \\
\hline Kadın & 72 & 46.15 & 501-1000 & 69 & 43.59 \\
\hline Toplam & 156 & 100.00 & $1001-2000$ & 29 & 18.59 \\
\hline Yaş & Sayı & $\%$ & $2001-3000$ & 12 & 7.69 \\
\hline $17-20$ & 31 & 19.87 & $3001-4000$ & 3 & 1.92 \\
\hline $21-24$ & 95 & 60.90 & $4001-5000$ & 5 & 3.21 \\
\hline $25-28$ & 14 & 8.97 & $5001-6000$ & 3 & 1.92 \\
\hline 29 ve üstü & 16 & 10.26 & $6001-7000$ & 1 & 0.64 \\
\hline Toplam & 156 & 100.00 & Toplam & 156 & 100.00 \\
\hline
\end{tabular}

\section{Geleneksel gıda ve tüketim tercihleri}

Çalışmada, geleneksel gıda denildiğinde akla ilk gelen ürünlerin neler olduğu sorulmuştur. Öğrenciler geleneksel gıda olarak çok sayıda ürün adı belirtmişler, ancak bu ürünler içinde en çok ifade edilen ürün künefe (\%21.79) olmuştur. Künefeyi çeşitli peynirler (\%19.23), yoğurtlar (\%19.23), içli köfte (\%17.31), kebap (\%14.74), tarhana (\%14.10) ve lahmacun (\%12.18) izlemiştir. Duru ve Seçer 'de (2019) yaptıkları çalışmada tüketicilerin, geleneksel ürün kavramını duyduklarında akıllarına gelen ürünlerin belirli ürün gruplarında yoğunlaşmamasına rağmen en sık ifade edilen ürünlerin yoğurt, peynir ve salça gibi evde hazırlanabilen ürünler olduğunu ifade etmişlerdir.

Öğrencilere okulun yemekhanesi haricinde ev dışında yemek yeme alışkanlıkları da sorulmuştur. Ankete katılan öğrencilerin en azından haftada 1 kez ev dışında yemek yedikleri ve fast food tercihlerinin geleneksel fast food ürünlerden yana olduğu Çizelge 2 'den görülmektedir. En çok tercih edilen ürün dönerdir ve geleneksel fast food tüketimi yabancı kökenli fast food tüketimine göre günde bir kez tüketimde 2.88 , haftada bir kez tüketimde 4.12 daha yüksektir. Acar (2016) üniversite öğrencilerinin fast food tercihleri üzerine yaptığı çalışmasında yerli fast food yiyeceklerin daha ekonomik olması nedeniyle daha çok tüketildiğini belirtmektedir. Tengiz (2018) de fast food yiyeceklerin ucuz olmasının tercihte etkili olduğunu, Canbolat ve Çakıroğlu (2016) ise tercihte kişisel nedenlerin öne çıktığını ve ürünle ilgili ilk nedenlerden birinin de fiyatının uygun olması (\%5.8) olduğunu tespit etmiştir.

Çizelge 2. Öğrencilerin ev dışında yemek yeme alışkanlığı ve sıklığı

Table 2. Dine-out habits and frequency of the students

\begin{tabular}{lccccc}
\hline Geleneksel gıdalar & Günde bir kez & Haftada bir kez & Ayda bir kere & Nadiren & Diğer \\
\hline Lahmacun & 0 & 27 & 57 & 65 & 7 \\
Döner & 15 & 72 & 34 & 31 & 4 \\
Künefe & 1 & 27 & 53 & 68 & 7 \\
Çiğköfte & 7 & 33 & 32 & 70 & 14 \\
İçli köfte & 0 & 10 & 35 & 87 & 24 \\
\hline Geleneksel fast food & $\mathbf{2 3}$ & $\mathbf{1 6 9}$ & $\mathbf{2 1 1}$ & $\mathbf{3 2 1}$ & $\mathbf{5 6}$ \\
\hline Hamburger & 6 & 26 & 46 & 56 & 22 \\
Pizza & 2 & 15 & 44 & 74 & 21 \\
\hline Yabancı fastfood & $\mathbf{8}$ & $\mathbf{4 1}$ & $\mathbf{9 0}$ & $\mathbf{1 3 0}$ & $\mathbf{4 3}$ \\
\hline Geleneksel/yabancl & $\mathbf{2 . 8 8}$ & 4.12 & 2.34 & 2.47 & 1.30 \\
\hline
\end{tabular}

Araştırmada geleneksel gıdaların evde ve ev dışında üretilme durumuna göre hangi sıklıkla tüketildikleri de sorulmuştur. Öğrencilerin \%62.82'si yoğurdu, \%38.46'si turşuyu, \%16.67'si sürk peynirini ve $\% 12.18^{\prime}$ i tuzlu yoğurdu her gün tüketirken, tuzlu yoğurdu \%26.92 oranında nadiren, tarhanayı \%26.92 oranla nadiren, sürkü \%19.87 oranla nadiren, külçeyi \%26.92 oranla nadiren, kömbeyi ise \%30.13 ile nadiren yediklerini belirtmişlerdir (Çizelge 3). 
Çizelge 3. Öğrencilerin evde üretilen geleneksel gıdaları tüketme sıklıkları

Table 3. Traditional food consumption of home-made by the students

\begin{tabular}{lrrrrrrrr}
\hline \multirow{2}{*}{ Ürünler } & \multicolumn{2}{c}{ Günde bir } & \multicolumn{3}{c}{ Haftada bir } & \multicolumn{2}{c}{ Ayda bir } & \multicolumn{2}{c}{ Nadiren } \\
\cline { 2 - 10 } & \multicolumn{1}{c}{ sayı } & \multicolumn{1}{c}{$\%$} & sayı & \multicolumn{1}{c}{$\%$} & sayı & \multicolumn{1}{c}{ sayı } & $\%$ \\
\hline Yoğurt & 98 & 62.82 & 38 & 24.36 & 9 & 5.77 & 8 & 5.13 \\
Tuzlu yoğurt & 19 & 12.18 & 16 & 10.26 & 17 & 10.90 & 42 & 26.92 \\
Tarhana & 5 & 3.21 & 24 & 15.38 & 18 & 11.54 & 42 & 26.92 \\
Turşu & 60 & 38.46 & 43 & 27.56 & 15 & 9.62 & 13 & 8.33 \\
Sürk & 26 & 16.67 & 14 & 8.97 & 15 & 9.62 & 31 & 19.87 \\
Künefe & 2 & 1.28 & 13 & 8.33 & 42 & 26.92 & 34 & 21.79 \\
Külçe & 2 & 1.28 & 5 & 3.21 & 17 & 10.90 & 42 & 26.92 \\
Kömbe & 4 & 2.56 & 10 & 6.41 & 27 & 17.31 & 47 & 30.13 \\
Diğer & 1 & 0.64 & 3 & 1.92 & 4 & 2.56 & 8 & 5.13 \\
\hline
\end{tabular}

Geleneksel gıdaların ev dışında tüketilme sıklıkları ve oranları Çizelge 4'de verilmiştir. Öğrencilerin genel olarak ev dışında üretilen gıdaları daha az tükettikleri ve ev dışı üretilen yoğurdun $\% 16.03$ ile günde bir kez tüketildiği, tuzlu yoğurdun $\% 22.44$ ile nadiren, tarhananın \%30.13 ile nadiren, turşunun \%16.03 ile nadiren, sürkün \%22.44 ile nadiren tüketildiği tespit edilmiştir (Çizelge 4). Öğrencilerin büyük kısmı ailelerinden ayrı yaşamakla birlikte (\%60.9) geleneksel gıda tüketiminde ev yapımı ürünlerin daha çok tüketildiği Çizelge 3 ve Çizelge 4'den anlaşılmaktadır. Başaran (2020) da Rize'de yaptığı bir çalışmada tüketicilerin geleneksel gıdaları çoğunlukla (\%92.4) evlerinde tükettiklerini belirlemiştir.

Çizelge 4. Öğrencilerin ev dışında üretilen geleneksel gıdaları tüketme sıklıkları

Table 4. Traditional food consumption away home by the students

\begin{tabular}{lrrrrrrrr}
\hline Ürünler & \multicolumn{2}{c}{ Günde bir } & \multicolumn{3}{c}{ Haftada bir } & \multicolumn{2}{c}{ Ayda bir } & \multicolumn{2}{c}{ Nadiren } \\
& sayı & \multicolumn{1}{c}{$\%$} & \multicolumn{1}{c}{ sayı } & \multicolumn{1}{c}{$\%$} & \multicolumn{1}{c}{ sayı } & \multicolumn{1}{c}{$\%$} & \multicolumn{1}{c}{ sayı } & $\%$ \\
\hline Yoğurt & 25 & 16.03 & 22 & 14.10 & 6 & 3.85 & 23 & 14.74 \\
Tuzlu yoğurt & 5 & 3.21 & 6 & 3.85 & 11 & 7.05 & 35 & 22.44 \\
Tarhana & 6 & 3.85 & 0 & 0.00 & 11 & 7.05 & 47 & 30.13 \\
Turşu & 14 & 8.97 & 19 & 12.18 & 10 & 6.41 & 25 & 16.03 \\
Sürk & 6 & 3.85 & 6 & 3.85 & 9 & 5.77 & 35 & 22.44 \\
Künefe & 2 & 1.28 & 15 & 9.62 & 35 & 22.44 & 32 & 20.51 \\
Külçe & 4 & 2.56 & 0 & 0.00 & 14 & 8.97 & 35 & 22.44 \\
Kömbe & 1 & 0.64 & 5 & 3.21 & 14 & 8.97 & 41 & 26.28 \\
\hline
\end{tabular}

*Birden fazla tercih yapılmıştır.

Geleneksel gıda tercihlerinde hayvansal ürünler ilk sırada yer almaktadır (Çizelge 5). Öğrencilerin en çok tercih ettiği geleneksel gıda \%74.36 ile süt ürünleri ve \%30.77 ile diğer hayvansal ürünler olmuştur. Çizelge 5 'den geleneksel gıdaların tercih edilme nedenlerinin \%66.67 ile güvenilir olması ve alışkın olma ve \%63.46 ile sağlıkı olma nedeniyle olduğu görülmektedir. Öğrencilerin $\% 25.64$ 'ü ise bütçelerine uygun olması nedeniyle tercih ettiklerini söylemişlerdir. Bu durum, geleneksel gıdaların temin yerleri ile de ilgili olup, öğrencilerin $\% 71.15^{\prime} i$ bu ürünleri annelerinin yaptığını ve $\% 41.67$ ' $i$ ise memleketten geldiğini ifade ettiği görülmektedir (Çizelge
5). Duru ve Seçer (2019) Mersin ilinde yaptıkları çalışmada; tüketicilerin geleneksel gıda ürünlerini genellikle marketlerden satın aldığını ve en çok süt ürünlerini tercih ettiklerini belirlemişlerdir. Taşdan ve ark. (2014) ise Ankara'da yaptıkları çalışmada geleneksel gıda satın alma yerleri olarak market, tanıdık/akraba, köyden getirtme ve üreticiden almayı en önemli seçenekler olarak belirlemişlerdir. Tüketicilerin gıda tercihlerinde sağlıklı beslenme konusundaki duyarlıı̆ı̆ı ise birçok araştırmada ortaya konmuştur (Kocatepe ve Tırıl, 2015; Başaran, 2016; Dölekoğlu ve Çelik, 2018; Tengiz, 2018). 
Çizelge 5. Geleneksel gıda tercihleri, nedenleri ve temin yeri*

Table 5. Traditional food preferences and reasons*

\begin{tabular}{lrrlrrlrr}
\hline Gıda tercihi & Sayı & $\%$ & Nedenleri & Sayı & $\%$ & Temin yeri & Sayı & $\%$ \\
\hline Süt ürünleri & 116 & 74.4 & Güvenilir olması & 104 & 66.7 & Marketten & 43 & 27.6 \\
Hayvansal ürünl. & 48 & 30.8 & Alıšıı olmamız & 104 & 66.7 & Annem yapıyor & 111 & 71.2 \\
Unlu mamuller & 58 & 37.2 & Bütçemize uygun olması & 40 & 25.6 & Memleketten geliyor & 65 & 41.7 \\
Konserve ürünler & 37 & 23.7 & Daha sağlıklı olması & 99 & 63.5 & Semt pazarından & 37 & 23.7 \\
Kurutmş gıdalar & 51 & 32.7 & Çok seviyor olmamız & 67 & 42.9 & Tanıdıklardan alıyoruz & 43 & 27.6 \\
Diğer & 4 & 2.6 & Kültürümüzü yansıtması & 75 & 48.1 & Üretim yerinden & 28 & 17.9 \\
& & & Diğer & 1 & 0.6 & Diğer & 4 & 2.6 \\
\hline
\end{tabular}

*Birden fazla tercih yapılmıştır.

Öğrenciler geleneksel gıda satın alırken hijyen şartları (5), son kullanma tarihi (5), tat ve aroma (5), koruyucu madde içermemesi (5) ifadelerini çok önemli bulduklarını, indirimli olması (4), promosyonlu olması (4), amblem ve logolu olması (4), üretilen firma (4), ambalaj (4), fiyat (4), marka (4), talep edilen ürün olması (4), organik olması (4) unsurlarını ise önemli bulduklarını ifade etmişlerdir. Duru ve Seçer (2019) yaptıkları çalışmada tüketicilerin geleneksel gıda satın alma davranışlarında kalite, tat ve aroma, gıda güvenliği, sağlıklı olması, koruyucu madde içermemesi ve son kullanma tarihinin etkili unsurlar olduğunu, fiyat, ambalaj, promosyon, ürünün büyüklügü̈, üretim yeri gibi konuların etkili unsurlar olmadığını belirlemişlerdir. Taşdan ve ark. (2014) Ankara'da yaptıkları çalışmada; tüketicilerin geleneksel gıda ürünleri satın alırken gıda güvenliği açısından üretim ve son tüketim tarihi, tazelik, fiyat ve katkı maddeleri listesi, saklama, hazırlama koşulları, ambalajlı olması, besin değeri ve ürünlerin markalarına dikkat ettiklerini belirlemişlerdir. Bu çalışmada ise öğrencilerin geleneksel gıda alırken cinsiyetleri ile hijyen şartları $(p=0,020)$, ürünlerin son kullanma tarihi $(p=0.033)$, koruyucu madde içermemesi $(p=0.023)$, talep edilen bir ürün olması $(p=0.037)$, organik olması $(p=0.000)$ arasında anlamlı bir ilişki olduğu belirlenmiştir. Yaş ile incelenen unsurlar arasında anlamlı bir ilişki bulunmazken, aile ile birlikte yaşama durumları ile üretilen firma $(p=0.018)$ ve ürün markası $(p=0.032)$ arasında anlamlı bir ilişki, gelir durumları ile indirimli olması ( $p=0.022)$, promosyonlu olması $(p=0.049)$, üretilen firma $(p=0.019)$ arasında anlamlı bir ilişki olduğu belirlenmiştir (Çizelge 6).

Çizelge 6. Öğrencilerin geleneksel gıda alırken önem verdikleri unsurlar

Table 6. Factors considered by the students while purchasing traditional food

\begin{tabular}{|c|c|c|c|c|c|}
\hline & Mod & $\begin{array}{c}\text { Cinsiyet } \\
(K / E)^{*}\end{array}$ & $\begin{array}{c}\text { Yaş grupları } \\
(17-20), \\
(21-24)(25-28) \\
(29-+)^{* *}\end{array}$ & $\begin{array}{l}\text { Aile ile birlikte } \\
\text { yaşam }(E / H)^{*}\end{array}$ & $\begin{array}{c}\text { Aylık gelir } \\
\text { grupları } \\
(0-1000 \\
1001-3000 \\
3001+)^{* *}\end{array}$ \\
\hline & & Sig. & Sig. & Sig. & Sig. \\
\hline Hijyen şartları & 5 & 0.020 & 0.809 & 0.526 & 0.708 \\
\hline Indirimli olması & 4 & 0.922 & 0.571 & 0.172 & 0.022 \\
\hline Son kullanma tarihi & 5 & 0.033 & 0.696 & 0.823 & 0.433 \\
\hline Promosyonlu olması & 4 & 0.273 & 0.163 & 0.077 & 0.049 \\
\hline Tat ve aroması & 5 & 0.086 & 0.514 & 0.619 & 0.236 \\
\hline Amblem/logolu olması & 4 & 0.107 & 0.693 & 0.577 & 0.450 \\
\hline Koruyucu madde içermemesi & 5 & 0.023 & 0.890 & 0.995 & 0.467 \\
\hline Üretilen firma & 4 & 0.279 & 0.398 & 0.018 & 0.019 \\
\hline Ambalajı & 4 & 0.118 & 0.421 & 0.166 & 0.162 \\
\hline Fiyat & 4 & 0.656 & 0.674 & 0.063 & 0.084 \\
\hline Markası & 4 & 0.182 & 0.769 & 0.032 & 0.469 \\
\hline Talep edilen bir ürün olması & 4 & 0.037 & 0.505 & 0.231 & 0.263 \\
\hline Organik olması & 4 & 0.000 & 0.460 & 0.796 & 0.722 \\
\hline
\end{tabular}

1:Kesinlikle katılmıyorum, 2:Katılmıyorum, 3:Fikrim Yok, 4:Katılıyorum, 5:Kesinlikle katılıyorum * Mann Witney U**Kruska Wallis 


\section{Geleneksel gıda ve coğrafi işaret farkındalığı}

Öğrencilerin geleneksel gıdalardan ne anladığı ve bunlarla ilgili çeşitli ifadelere katılıp katılmadıkları da likert tipi sorular ile değerlendirilmiștir. Öğrenciler geleneksel gıda satın alırken markanın önemli olduğunu belirtmelerine karşın, geleneksel gıdayı tanımlarken "markası yoktur" ifadesi ile ilgili olarak bu konuda fikirlerinin olmadığını (3) belirtmişlerdir. Öğrencilerin sadece \%28.80'i "markası yoktur" ifadesine katılmadıklarını belirtmişlerdir. Bunun dışındaki diğer tüm tutum ifadelerine katılmışlardır(4). Başaran'ın (2016) yaptığı çalışmada ise tüketicilerin tamamı geleneksel gıdaları yöresel hammaddeler kullanarak yapılan gıdalar olarak tanımlamakta ve deneklerin yarısı ise bölgede en fazla tüketilen gıda olarak görmektedir. Araştırma kapsamında öğrencilerin geleneksel gıdalar denildiğinde ne anladıkları ile cinsiyetleri, yaşları, aile ile birlikte yaşama durumları ve aylık gelirleri arasında istatistiki bakımdan anlamlı bir ilişki olup olmadığı incelenmiştir. Cinsiyetlerine göre yapılan karşılaştırmada, toplumda en çok tüketilen gıda olduğu $(p=0.001)$, bir bölgede en çok üretilen gıda olduğu $(p=0.009)$, bölgede en çok tanınan ürün olduğu $(p=0.020)$ ve organik gıda olduğu $(p=0.033)$ konusundaki düşünceleri arasında anlamlı bir ilişki olduğu belirlenmiştir. Yaş gruplarına göre yapılan karşılaştırmada sadece yöresel ürünler/malzemeler kullanıldığı $(p=0.043)$ ifadesi ile anlamlı bir ilişki tespit edilmiştir. Aile ile birlikte yaşama durumları ile geleneksel gıdaların bir bölgeye ait yöresel özellikler içeren gıda oldukları $(p=0.027)$ ve öğrencilerin aylık gelirleri ile geleneksel gıdaların yöresel ürün/malzemeler kullanılarak yapıldığı ifadesi arasında anlamlı bir ilişki bulunmaktadır ( $p=0.036$ ) (Çizelge 7).

Çizelge 7. Öğrencilerin geleneksel gıdalardan anladıkları

Table 7. Perception of students on what is a traditional food

\begin{tabular}{|c|c|c|c|c|c|}
\hline & Mod & $\begin{array}{c}\text { Cinsiyet } \\
(K / E)^{*}\end{array}$ & $\begin{array}{c}\text { Yaş grupları } \\
(17-20), \\
(21-24)(25-28) \\
(29-+)^{* *}\end{array}$ & $\begin{array}{l}\text { Aile ile } \\
\text { birlikte } \\
\text { yaşam } \\
(E / H)^{*}\end{array}$ & $\begin{array}{c}\text { Aylık gelir } \\
\text { grupları } \\
\text { (0-1000 } \\
1001-3000 \\
3001+)^{* *}\end{array}$ \\
\hline Tonlumda en cok tüketilen aıdalardır & 1 & sig. & $\frac{3 \lg .}{0.06}$ & SIg. & Sig. \\
\hline Bir bölgede en çok üretimi yapılan gıdalardır & 4 & 0.009 & 0.247 & 0.469 & 0.856 \\
\hline Bir bölgeye ait yöresel özellikleri içeren gıdalardır & 4 & 0.449 & 0.846 & 0.027 & 0.066 \\
\hline Annelerimizin yaptığı gıdalardır & 4 & 0.721 & 0.076 & 0.937 & 0.676 \\
\hline Katkı maddesi içermeyen gıdadır & 4 & 0.095 & 0.830 & 0.631 & 0.624 \\
\hline Eskiden beri yapılan gıdalardır & 4 & 0.901 & 0.804 & 0.077 & 0.841 \\
\hline Bölgede en çok tanınan üründür & 4 & 0.020 & 0.804 & 0.193 & 0.587 \\
\hline Organik gıdadır & 4 & 0.033 & 0.231 & 0.574 & 0.705 \\
\hline Yöresel ürünler/malzemeler kullanılarak yapılır & 4 & 0.057 & 0.043 & 0.278 & 0.036 \\
\hline Markası yoktur & 3 & 0.095 & 0.698 & 0.222 & 0.702 \\
\hline
\end{tabular}

1:Kesinlikle katılmıyorum, 2:Katılmıyorum, 3:Fikrim Yok, 4:Katılıyorum, 5:Kesinlikle katılıyorum

* Mann Witney $U{ }^{* *}$ Kruska Wallis

Öğrencilere geleneksel gıdalar hakkındaki çeşitli ifadelere katılma durumları likert tipi sorular ile sorulmuştur. Öğrenciler geleneksel gıdalar ile ilgili tutum ifadelerinden sadece geleneksel gıdaların ucuz olduğu tutum ifadesine katılmadıklarını (2) , diğer tüm ifadelere katıldıklarını (4) belirtmişlerdir. Geleneksel gıdaların coğrafi işaret olmadığını düşünenler (\%6.40) ile fikri olmadığını söyleyenler (\%10.30) 26 kişi olmuş ve çoğunlukla "coğrafi işarettir" ifadesine katılmışlardır.
Cinsiyet ile geleneksel gıdaların kültürümüzü korudukları ifadesi $(p=0.008)$, yaş grupları ile coğrafi işarettir ifadesi $(p=0.046)$, öğrencilerin aile ile birlikte yaşama durumları ile geleneksel gıdaların güvenilir gıdalar olduğu $(p=0.049)$ ve katma değer yarattığı ifadesi $(p=0.008)$ ve aylık gelirlerine göre geleneksel gıdaların ucuz olduğu ifadesi $(p=0.031)$ arasında anlamlı bir ilişki bulunmuştur (Çizelge 8). 
Çizelge 8. Öğrencilerin geleneksel gıdalar ile ilgili ifadelere katılım durumu Table 8. Opinions of the students on the statements given in the survey about traditional food

\begin{tabular}{|c|c|c|c|c|c|}
\hline & Mod & $\begin{array}{c}\text { Cinsiyet } \\
(K / E)^{*} \\
\text { Sig. }\end{array}$ & $\begin{array}{c}\text { Yaş grupları } \\
\text { (17-20), } \\
(21-24)(25-28) \\
(29-+)^{* *} \\
\text { Sig. }\end{array}$ & $\begin{array}{c}\text { Aile ile } \\
\text { birlikte } \\
\text { yaşam } \\
(E / H)^{*} \\
\text { Sig. }\end{array}$ & $\begin{array}{l}\text { Aylık gelir } \\
\text { grupları } \\
\text { (0-1000 } \\
1001-3000 \\
3001+)^{* *} \\
\text { Sig. }\end{array}$ \\
\hline Geleneksel gıdalar doğaldır & 4 & 0.084 & 0.953 & 0.056 & 0.504 \\
\hline Geleneksel gıdalar lezzetlidir & 4 & 0.236 & 0.455 & 0.207 & 0.644 \\
\hline Geleneksel gıdalar daha sağlıklıdır & 4 & 0.152 & 0.953 & 0.311 & 0.471 \\
\hline Geleneksel gıdalar güvenilirdir & 4 & 0.253 & 0.678 & 0.049 & 0.933 \\
\hline Geleneksel gidalar temizdir & 4 & 0.277 & 0.691 & 0.202 & 0.559 \\
\hline Geleneksel gıdalara daha kolay erişilir & 4 & 0.942 & 0.855 & 0.365 & 0.445 \\
\hline Geleneksel gıdalar ucuzdur & 2 & 0.058 & 0.399 & 0.094 & 0.031 \\
\hline Bölge/yöreyi tanıtır/ünlü yapar & 4 & 0.073 & 0.410 & 0.638 & 0.591 \\
\hline Katma değer(artı değer) yaratır & 4 & 0.271 & 0.850 & 0.008 & 0.786 \\
\hline Kültürümüzü korur & 4 & 0.008 & 0.472 & 0.223 & 0.430 \\
\hline Coğrafi Işsarettir & 4 & 0.087 & 0.046 & 0.751 & 0.636 \\
\hline
\end{tabular}

1:Kesinlikle katılmıyorum, 2:Katılmıyorum, 3:Fikrim Yok, 4:Katılıyorum, 5:Kesinlikle katılıyorum

* Mann Witney $U{ }^{* *}$ Kruska Wallis

Tüketiciler geleneksel gıdaların öneminin yeterli düzeyde algılanmadığını söylemekte ve geleneksel gıdaların kültürümüzün yansıması olduğunu kabul etmektedirler (Başaran,2016). Bu çalışmadaki denekler de geleneksel gıdaların yöresel özelliklere sahip olduğunu ve kültürü koruduğu ifadelerine katıldıklarını belirtmişlerdir (Çizelge 7 ve Çizelge 8). Bu ifadelerin doğal sonucu olarak da deneklerin neredeyse tamamı geleneksel gıdaların korunması gerektiğini (\%98.10) belirtmişlerdir (Çizelge 9). Korunma nedenleri olarak kültürümüzü yansıtması (\%59.62) ve damak tadına uygunluk (\%50.64) öne çıkmaktadır. Geleneksel ürünlerin korunmasının ise yeni nesillere öğreterek (\%67.31), üretimi artırarak (\%62.83) ve tanıtımla (\%58.97) sağlanacağı ifade edilmiştir. Tescil ile koruma ise 44 kişi (\%28.21) tarafından koruma yöntemi olarak söylenmiştir.

Çizelge 9. Geleneksel gıdaların korunması ile ilgili düşünceler Table 9. Thoughts about protection of traditional food

\begin{tabular}{|c|c|c|c|c|c|}
\hline Korunma nedeni & Sayı & $\%$ & Nasıl korunacağı & Sayı & $\%$ \\
\hline Gelir getirdiği için & 20 & 12.82 & Üretimi artırarak & 98 & 62.82 \\
\hline Damak tadımıza uyduğu için & 79 & 50.64 & Tüketimi artırarak & 76 & 48.72 \\
\hline Daha sağlıklı olduğu için & 71 & 45.51 & $\begin{array}{l}\text { Tanıtım yaparak } \\
\text { Yeni nesile }\end{array}$ & 92 & 58.97 \\
\hline Doğal olduğu için & 63 & 40.38 & öğreterek & 105 & 67.31 \\
\hline Kültürümüzü yansıttığı için & 93 & 59.62 & Tescille & 44 & 28.21 \\
\hline Katkı maddesi içermediği için & 21 & 13.46 & Evde yaparak & 18 & 11.54 \\
\hline Daha hijyenik olduğu için & 10 & 6.41 & & & \\
\hline Atalardan miras kaldığı için & 33 & 21.15 & & & \\
\hline Ucuz olduğu için & 3 & 1.92 & & & \\
\hline Her yerde bulunduğu için & 1 & 0.64 & & & \\
\hline Yerli malı olduğu için & 39 & 25.00 & & & \\
\hline
\end{tabular}

*Birden fazla tercih işaretlenmiştir.

Öğrencilerin \%66.00'ı daha önce coğrafi işareti duyduğunu belirtmiş ve bunun kaynağını internet
(\%22.40), televizyon (\%11.50) ve yazılı basın (\%7.70) olarak ifade etmiştir. Coğrafi işareti duyduğunu söyleyen 
103 öğrencinin 72'si (\%69.9) ise coğrafi işaret olarak bildiği ürünler olduğunu belirtmiştir. Bu ürünler içinde yine en çok bilinenler Antakya Künefesi olup, tüm öğrencilerin ancak \%11.54'ünün Antakya Künefesinin coğrafi işaret olduğunu bildikleri anlaşılmaktadır. Antakya Künefesini Adana Kebabı (\%5.13), Antep Baklavası (\%4.49) ve Antakya Sürkü (\%3.21) takip etmiştir. Hatay'ın coğrafi işaretli ürünleri olan Antakya Tuzlu Yoğurdu 3 öğrenci (\%1.92) ve Hatay Defne Sabunu ise 1 öğrenci tarafından coğrafi işaretli ürün olarak ifade edilmiştir.

Geleneksel gıdaların korunmasında olduğu gibi öğrencilerin neredeyse tamamı (\%98.70) geleneksel gıdaların teşvik edilmesi gerektiğini söylemişlerdir. Ancak, bu ürünlerin ihracat şansını öğrencilerin sadece \%29.48'ı yüksek bulmaktadır. Oysa, günümüzde küreselleşme ile tercihler birbirine yaklaşıp, standart ürünlere yönelme olsa da yerel ürünler ve farklılaşma pazarda tutunabilmenin en önemli yolu olmuştur (Demirbaş ve ark., 2006; Tepe, 2008).

Sonuç olarak, küresel piyasalardaki gelişmeler ve gıda güvenliği ile ilgili kaygılar ürünlerin kaynağına ve coğrafi işaretlere olan ilginin artmasına neden olmuş ve bu ürünler giderek artan bir ekonomik güce dönüşmüştür. Bu süreçte, ülkelerin kendi geleneksel ürünlerine sahip çıkabilmeleri, tanıtmaları ve toplumsal farkındalık yaratılması önemlidir.

Bu çalışmada, üniversite öğrencilerinin geleneksel gıdalar konusundaki farkındalıkları incelenmiş ve mevcut durum tespiti yapılmıştır. Öğrencilerin en önemli özelliği tüketim potansiyeli yüksek yaş grubunda olmaları, ailelerinden ayrı yaşamaları $(\% 60.90)$ ve önemli bir bölümünün (\%22.44) aylık 500 TL'nin altında kişisel gelirlerinin olmasıdır. Öğrencilerin geleneksel gıda olarak belirtikleri birçok ürün içinde öne çıkanlar künefe (\%21.79), çeşitli peynirler (\%19.23), yoğurtlar (\%19.23), içli köfte (\%17.31), kebap (\%14.74), tarhana (\%14.10) ve lahmacun (\%12.18) olmuştur. Ev dışındaki hazır gıda tüketimlerinde ise geleneksel gıdalar daha çok tercih edilmekte ve öğrencilerin \%25.64'ü geleneksel gıdaları tercih etme nedenlerini bütçelerine uygun olması olarak belirtmektedirler. Geleneksel gidaların temin yolları ise anne yapımı olması ( $\% 71.15$ ) ve memleketten (\%41.67) gelmesidir. Öğrencilerin bu gıdaları satın alırken önem verdikleri son kullanma tarihi, koruyucu madde içermemesi, organik olması ve talep edilen bir ürün olması ile cinsiyet arasındaki ilişki anlamlı bulunurken, gelire göre indirimli ürün olması, üretilen firma ve promosyon anlamlı bulunmuştur. Öğrencilerin \%66.00'ı daha önce coğrafi işareti duyduğunu söylemiş ve bunların \%69.9'u (72 kişi) coğrafi işaret olarak bildiği ürünler olduğunu belirtmiştir. En çok bilinen coğrafi işaretli ürünler Antakya Künefesi (\%11.54), Adana Kebabı (\%5.13), Antep Baklavası (\%4.49) ve Antakya Sürkü (\%3.21)'dür. Çalışmaya katılanların büyük kısmı (\%98.10) geleneksel gıdaların korunması gerektiğini belirtmiş ve bunun nedeni olarak kültürümüzü yansıtması (\%59.62) ve damak tadına uygun olması gösterilmiştir. Geleneksel ürünlerin korunmasının ise yeni nesillere öğreterek (\%67.31), üretimi artırarak (\%62.83) ve tanıtımla (\%58.97) sağlanacağı ifade edilmiştir. Tescil ile koruma ise 44 kişi (\%28.21) tarafından koruma yöntemi olarak ifade edilmiştir.

Geleneksel gıdaların bir kısmı herkes tarafından tüketilen ve bilinen ürünler olmakla birlikte, bazı ürünler ise çok az sayıda üretici ve tüketici tarafından bilinmektedir. Bu nedenle, Türkiye'nin sahip olduğu ürün çeşitliliğinin korunması için bu ürünlerin tespit edilmesi, ürün standardının ve farklılıklarının belirlenmesi ve tescili sağlanmalıdır. Bu ürünlerin kırsal kalkınma aracı olabilmesi için de ürünler için pazarlama stratejilerinin geliştirilmesi önemlidir. Bu nedenle, sahada üreticilerle yüz yüze çalışacak olan geleceğin Ziraat Mühendislerinin konu hakkındaki farkındalıklarının artması önemlidir.

\section{ÖZET}

Amaç: Bu çalışma, ziraat fakültesi öğrencilerinin geleneksel gıdalar ve coğrafi işaretler konusundaki farkındalıklarını belirlemek amacıyla yapılmıştır.

Yöntem ve Bulgular: Çalışma, Hatay Mustafa Kemal Üniversitesi Ziraat Fakültesinde lisans düzeyinde öğrenim gören 156 öğrenci ile gerçekleştirilmiştir. Öğrencilerin geleneksel gıda olarak belirtikleri birçok ürün içinde öne çıkanlar künefe (\%21.79), çeşitli peynirler (\%19.23), yoğurtlar (\%19.23), içli köfte (\%17.31), kebap (\%14.74), tarhana (\%14.10) ve lahmacun (\%12.18) olmuştur. Ev dışındaki hazır gıda tüketimlerinde ise geleneksel gıdalar daha çok tercih edilmekte ve \%25.64'ü geleneksel gıdaları tercih etme nedenlerini bütçelerine uygun olması olarak belirtmektedirler. Öğrenciler geleneksel ürünlerin korunması (\%98.10) ve teşvik (\%98.70) edilmesi gerektiğini düşünmektedir. Öğrencilerin \%66.00'ı coğrafi işareti daha önce duyduğunu söylemiş ve bunların \%69.90' । (72 kişi) ise coğrafi işaret olarak bildiği ürünler olduğunu belirtmiştir. Bu ürünler içinde yine en çok bilinen Antakya Künefesi olup, tüm öğrencilerin ancak \%11.54'ünün Antakya Künefesinin coğrafi işaret olduğunu bildikleri anlaşılmaktadır. Antakya Künefesini Adana Kebabı (\%5.13), Antep Baklavası (\%4.49) ve Antakya Sürkü (\%3.21) takip etmiştir. Hatay'ın coğrafi işaretli ürünleri olan Antakya Tuzlu Yoğurdu 3 öğrenci (\%1.92) ve Hatay Defne Sabunu ise 1 öğrenci tarafından 
coğrafi işaretli ürün olarak ifade edilmiştir.

Genel Yorum: : Türkiye, kültürel ve coğrafi çeşitliliği ile geleneksel ürünler bakımından büyük bir potansiyele sahiptir. Ancak, bu potansiyelin çok küçük bir kısmı görünür durumdadır. Bu potansiyelin ortaya çıkarılması ve ekonomiye kazandırılmasında Ziraat Mühendislerine önemli görevler düşmektedir.

Çalışmanın Önemi ve Etkisi: Bu çalışma, sahada üreticilerle yüz yüze çalışacak olan geleceğin Ziraat Mühendislerinin konu hakkındaki farkındalıklarının ortaya konması ve daha sonra planlanacak çalışmaları geliştirmesi bakımından önemlidir.

Anahtar Kelimeler: Geleneksel gıda, coğrafi işaret, tüketici tercihi.

\section{ÇIKAR ÇATIŞMA BEYANI}

Yazar(lar) çalışma konusunda çıkar çatışmasının olmadığını beyan eder.

\section{ARAŞTIRMACILARIN KATKI ORANI BEYANI}

Yazarlar makaleye eşit oranda katkı sağlamış olduklarını beyan ederler.

\section{KAYNAKLAR}

Acar A (2016) Yerli ve yabancı fastfood ürünlerinin gençlerin tercih nedenlerinin belirlenmesi üzerine bir alan çalışması: Muğla Sıtkı Koçman Üniversitesi örneği. Sosyal ve Beşeri Bilimler Araştırmaları Dergisi 17( 38): 1-24.

Altuntaş A, Gülçubuk B (2014) Yerel kalkınmada yaygınlaşan bir araç olarak geleneksel gıdalar ve geleneksel gıda mevzuatının yaygınlaştırılabilirliği. JAFAG 31(3): 73-81.

Anonim (2015) Ulusal Coğrafi İşaret Strateji Belgesi ve Eylem Planı (2015-2018), 04.07.2015 tarih ve 29406 sayılı Resmi Gazete.

Anonim (2017) Sinai Mülkiyet Kanunu. 10 Ocak 2017 tarih ve 29944 sayılı Resmi Gazete. www.resmigazete.gov.tr (Erişim Tarihi: 10 Ocak 2021)

Anonim (2017a) Sinai Mülkiyet Kanununun Uygulanmasına Dair Yönetmelik. 24 Nisan 2017 tarih ve 30047 sayılı resmi gazete. www.resmigazete.gov.tr (Erişim Tarihi: 10 Mayıs 2021).

Anonymous (2012) Verordnung (EU) Nr. 1151/2012 des Europäıschen Parlaments und des Rates vom 21. November 2012 über Qualitätsregelungen für Agrarerzeugnisse und Lebensmittel. https://eurlex.europa.eu/legalcontent/DE/TXT/PDF/?uri=CELEX:32012R11 51\&from=en (Erişim Tarihi: 30 Mayıs 2021)

Başaran B (2016) Trabzon'da yaşayan tüketicilerin geleneksel gıdalara yönelik tutum ve algıları. JAFAG 33(1): 99-110.

Başaran B (2020) Yöre halkının geleneksel gıda tüketim eğilimi: Rize örneği. Türk Turizm Araştırmaları Dergisi 4(4): 3411-3427.

Canbolat E, Çakıroğlu FP (2016) Üniversite öğrencilerinin fast-food tüketim alışkanlıkları. Akademik Sosyal Araştırmalar Dergisi 4(26): 473-481.

Çoksöyler N (2011) Geleneksel gıda denince ne anlaşılıyor? Halkta geleneksel gıda algısı nedir? Gıda\&Yem Analiz'35, 10: 4-6., http://gidalab.tarim.gov.tr/izmir/Belgeler/Analiz\%20 35/dergi10.pdf (Erişim Tarihi: 01 Mayıs 2021)

Dölekoğlu C, Çelik O (2018) Y kuşağı tüketicilerin gıda satın alma davranışı. KSÜ Tarım ve Doğa Derg. 21: 5566.

Duru S, Seçer A (2018) Geleneksel gıda ürünlerini satın alma davranışları ve tutumları: Mersin ili örneği. Atatürk Univ. J. of the Agricultural Faculty 50(1): 1-10.

Demirbaş N, Oktay D, Tosun D (2006) AB sürecinde Türkiye'de gıda güvenliği açısından geleneksel gıdaların üretim ve pazarlanması. Harran Üniversitesi Ziraat Fakültesi Dergisi 10(3/4): 47-55.

Haşıloğlu SB, Baran T, Aydın O (2015) Pazarlama araştırmalarındaki potansiyel problemlere yönelik bir araştırma: Kolayda örnekleme ve sıklık ifadeli ölçek maddeleri. PIBYD 2(1): 19-28.

Hermann R, Marauhn T, Teuber R (2008) Der Schutz geographischer Herkunftsangaben: Herausforderungen für agrarökonomische, rechtswissenschaftliche und interdisziplinaere Forschung. Agrarwirtschaft 57 Heft 7: 321-324.

Johannes R (2010) Bewertung der ökonomischen Auswirkungen von den geschützten geographischen Herkunftsbezeichungen der EU mittels Experteninterviews in Österreich, Üniversitaet für Bodenkultur, Department für Wirtschafts- und Sozialwissenschaften Institut für Marketing und Innovation, Diplomarbeit, Novewber 2010, Wien.

Kantaroğlu M, Demirbaş N (2018) Türkiye'de coğrafi işaretli gıda ürünleri üretim potansiyelinin değerlendirilmesi. VIII. IBANESS Congress Series, April 21-22, 2018, Plovdiv / Bulgaria, 514-520.

Kocatepe D, Tırıl A (2015) Sağlıklı beslenme ve geleneksel gıdalar. Journal of Tourism and Gastronomy Studies 3(1): 55-63.

Keskin G (2017) Türkiye'de tarımsal potansiyelin gizli gücü: coğrafi işaretler ve geleneksel ürün adları. Ahi Evran Üniversitesi iïBF Dergisi 1(1): 115-128. 
Keskin G, Dağıstan E (2020) Geographical indications and traditional products as instruments of rural development: The example of Hatay, a cultural crossroads. MKU. Tar. Bil. Derg. 25(2): 101-107.

May S, Tschofen B (2016) Regionale Spezialitäten als globales Gut. Inwertsetzungen geografischer Herkunft und distinguierender Konsum, Zeitschrift für Agrargeschichte und Agrarsoziologie. 64. Jg. / Heft 2: 61-75.

Oraman Y, Unakıtan G, Yılmaz E, Başaran B (2011) Analysis of the factor affecting consumer's some traditional food products preferences by multidimensional scaling method. Journal of Tekirdağ Agricultural Faculty 8(1): 33-40.

Onurlubaş E, Taşdan K (2017) Geleneksel ürün tüketimini etkileyen faktörler üzerine bir araştırma. AiBü Sosyal Bilimler Enstitüsü Dergisi 17(17): 115-132.

Özdemir G, Yılmaz E, Unakıtan G, Yılmaz i, Keskin G (2015) Trakya bölgesinde geleneksel gıdaların ekonomiye kazandırımasında kırsal kadının rolü ve örgütlenme olanakları. NKU BAP 2014-2015.

Özdemir G, Yılmaz E, Unakıtan G, Yılmaz I, Keskin G (2017) Kırsalda kadının geleneksel gıda üretimi ve pazarlama istekliliği. JOTAF 14(3): 66-72.

Tan E (2004). Türkiye'de geleneksel gıda ürünleri projesi, I. Geleneksel Gıdalar Sempozyumu, 23-24 Eylül, Van.
Taşdan K, Albayrak M, Gürer B, Özer O, Albayrak K, Güldal HT (2014) Geleneksel gıdalarda tüketicilerin gıda güvenliği algısı: Ankara ỉli Örneği. In: 2. Uluslararası Davraz Kongresi, 29-31 Mayıs, Isparta, Türkiye, Bildiriler Kitabı, s. 363-386.

Tengiz ZM (2018) Üniversite öğrencilerinin fast food tüketimine yönelik tutum ve davranışlarının değerlendirilmesi. Tekirdağ NKU Fen Bilimleri Enstitüsü, Yüksek Lisans Tezi, Tekirdağ.

Tepe S (2008) Coğrafi İşaretlerin Ekonomik Etkileri. TPE Markalar Dairesi Başkanlığı, Uzmanlık Tezi, Ankara.

TOB (2009) Geleneksel gıda ürünlerinde gıda güvenliği açısından tüketici algısının belirlenmesi ve geleneksel gıda ürünü üreten kobi'lere pazar payı artırım yollarının belirlenmesi (GEGÜP). TAGEM Ar-Ge Projeleri, https://www.setbir.org.tr/hbr.php?id=74 (Erişim Tarihi: 28 Mayıs 2021).

TOB (2021) Tarım ve Orman Bakanlığı Stratejik Plan (2019-2023). https://www.tarimorman.gov.tr (Erişim Tarihi: 26 Mayıs 2021).

TOB (2021a) Coğrafi işaretlerde farkındalığın artırıması projesi. https://www.tarimorman.gov.tr/SGB (Erişim Tarihi: 20 Mayıs2021).

Turan İ, Şimşek Ü, Aslan H (2015) Eğitim araştırmalarında likert ölçeği ve likert-tipi soruların kullanımı ve analizi. SUEFD (30): 186-203. 